\title{
INVENTING INDIA
}


This page intentionally left blank 


\title{
Inventing India
}

A History of India in English-Language Fiction

\author{
Ralph J. Crane
}


(C) Ralph J. Crane 1992

Softcover reprint of the hardcover 1st edition 1992 978-0-333-56363-2

All rights reserved. No reproduction, copy or transmission of this publication may be made without written permission.

No paragraph of this publication may be reproduced, copied or transmitted save with written permission or in accordance with the provisions of the Copyright, Designs and Patents Act 1988, or under the terms of any licence permitting limited copying issued by the Copyright Licensing Agency, 90 Tottenham Court Road, London W1P 9HE.

Any person who does any unauthorised act in relation to this publication may be liable to criminal prosecution and civil claims for damages.

First published 1992 by THE MACMILLAN PRESS LTD

Houndmills, Basingstoke, Hampshire RG21 2XS and London

Companies and representatives throughout the world

ISBN 978-1-349-39062-5 ISBN 978-0-230-38008-0 (eBook) DOI $10.1057 / 9780230380080$

A catalogue record for this book is available from the British Library. 
For Joy, of course, and for Jennifer Livett 
This page intentionally left blank 


\section{Contents}

List of Plates

viii

Prefatory Note ix

Acknowledgements

1 Introductory: Fiction as History

2 The Great Revolt: 1857

3 The Period of the Great Game

4 Bridges

5 Swaraj

100

6 Partition

136

7 The End of the Old Order

152

8 The Chutnification of History

9. Epilogue

Notes and References

Select Bibliography

Index

208 


\section{List of Plates}

1. Thomas Jones Barker, The Relief of Lucknow

2. 'The Courtyard of the Secunderbagh'

3. Abraham Solomon, The Flight from Lucknow

4. The Jewel in Her Crown

5. Sir Edwin Landseer, The Monarch of the Glen

6. Jean Antoine Watteau, L'Embarquement pour L'île de Cythère

7. John Everett Millais, The Boyhood of Raleigh 


\section{Prefatory Note}

In the interests of consistency, I have referred to the British community in India as Anglo-Indians throughout this study. Similarly, I have used the term Eurasian to describe the mixed-race community, despite the fact that after the census of 1911 these people were officially recognised as Anglo-Indians.

Many Indian words have no definitive English spelling. As Olivia writes in O. Douglas's Olivia in India: 'One trait [Hindustani] has which appeals to me is that one can spell it almost any way one likes'. I have been consistent throughout my own text, but various spellings of words like chapati and Muslim appear in quotations. 


\section{Acknowledgements}

This book was first conceived as a doctoral thesis at the University of Tasmania. I am indebted to that institution for the provision of the Estelle Taylor Postgraduate Research Award from November 1985 to October 1989. I would also like to express my appreciation to everyone in the English Department at the University of Tasmania, for their encouragement during four very happy years.

I am grateful to the following for their kind permission to reproduce photographs: the Leicestershire Museums for The Flight from Lucknow; Messrs John Dewar and Sons Ltd for The Monarch of the Glen; the Verwaltung der Staatlichen Schlösser und Gärten, Berlin, for L'Embarquement pour L'île de Cythère; the Tate Gallery, London, for The Boyhood of Raleigh. The Relief of Lucknow and "The Courtyard of the Secunderbagh' appear courtesy of the Director, National Army Museum, London. The Jewel in Her Crown appears courtesy of Granada Television, Manchester, England. 
It is not down on any map; true places never are.

(Herman Melville, Moby-Dick) 